\title{
Stratejik İnsan Kaynakları Yönetimi Aracının Liyakate Esas Görüşlerle Olan İlişkisi: Sağlık Çalışanları Örneği
}

\section{The Relationship Between the Strategic Human Resources Management Tool and the Views on Merit: Healthcare Professionals}

\author{
Dr. Öğr. Üyesi Altuğ ÇAĞATAY (iD) 1 , Dr. Selman KIZILKAYA ${ }^{(D 2}$
}

\begin{abstract}
$\ddot{\mathbf{O} z}$
$\mathrm{Bu}$ çalışmanın amacı, bir stratejik yönetim aracı olan insan kaynakları yönetimi uygulamaları ve liyakat ilkelerine ilişkin görüşler arasındaki ilişkinin incelenmesidir. Araştırmada veri toplama yöntemi olarak anket tekniği kullanılmıştır. Anket çalışması Ordu ilindeki özel ve kamu hastanelerinin çalışanlarına uygulanmıştır. Araştırma için on üç hipotez belirlenmiş ve hipotezlerin doğruluğunu test etmek için korelasyon analizi, Mann-Whitney U testi ve Kruskal-Wallis H testi uygulanmıştır. Sonuç olarak, katılımcıların insan kaynakları uygulamalarına ilişkin görüşleri ile liyakat ilkelerine ilişkin görüşleri arasında anlamlı düzeyde ve pozitif yönde bir ilişki olduğu tespit edilmiştir. Bunun yanında cinsiyet ve öğrenim düzeyi değişkenlerine göre insan kaynakları uygulamaları ve liyakat ilkelerine yönelik görüşler arasında anlamlı bir farklılık olmadığı ortaya çıkmış iken çalışılan branş, kurumda çalışma nedeni, kaç defa kurum içi yer değişikliğinde bulunulduğu, toplam çalışma süresi değişkenlerine göre anlamlı bir farklılık olduğu tespit edilmiştir.
\end{abstract}

Anahtar Kelimeler: İnsan kaynakları, liyakat, liyakat ilkeleri

Makale Türü: Araştırma

\begin{abstract}
This study aims to examine the relationship between human resources management practices as a strategic management tool and opinions on merit principles. survey technique was used as the data collection method. The survey was applied to employees of private and public hospitals in Ordu. The study has thirteen hypotheses, and correlation analysis, the Mann-Whitney U test, and the Kruskal-Wallis H test were applied to test the accuracy of the hypotheses. It was determined that there was a significant and positive relationship between the opinions of the participants on human resources practices and the merit principles. In addition to this, there is no significant difference between human resources practices and opinions regarding merit principles according to gender and education level variables, whereas there is a significant difference according to the department, the reason for working in the institution, number of intraorganizational change of position, and the total service year variables.
\end{abstract}

Keywords: Human resources, merit, merit principles

Paper Type: Research

\footnotetext{
${ }^{1}$ Tokat Gaziosmanpaşa Üniversitesi Almus Meslek Yüksekokulu, altug.cagatay@ gop.edu.tr.

${ }^{2}$ ODTÜ Bilimsel Araştırma Merkezi, kselman@metu.edu.tr.
}

Atıf için (to cite): Çağatay, A. ve Kızılkaya, S. (2021). Stratejik insan kaynakları yönetimi aracının liyakate esas görüşlerle olan ilişkisi: Sağlık çalışanları örneği. Afyon Kocatepe Üniversitesi Sosyal Bilimler Dergisi, 23(1), 249-267. 


\section{Giriş}

Bilimsel yönetim hususunun çıkışı olarak kabul edilen Frederick Winslow Taylor dan bu yana, insan kaynağının hangi şartlar ve amaçlara ilişkin yöneltileceği çalışmalarında bulunulmuştur. Bir iş akışı şeması çerçevesinde şekillenen bu durum insan öğesinin varlığının emek konumunda nasıl hareket kabiliyeti kazandırdığını bilimsel ilkelerle ortaya koymuştur. Bugün ise insan kaynağının etkili ve verimli çalışmasının esasları, normları, bakış açıları ve makul kabul halleri hem çalışan akranlarca gözlemlenmekte hem de atama yönlendirme yapan yöneticiler içinde bir sorgulama nedeni haline gelmiştir.

İKY hem bir çalışma hem de bir uygulama alanıdır. Örgüt içindeki insanların yönetimi için örgütün resmi sistemini planlama, bulma, inşa etme, koordine etme, kullanma ve bu resmi sistemi ele alma sürecine odaklanmaktadır. Peretomode (2001)' a göre İKY, insanları ve örgütleri bir araya getirme sürecidir ve böylece her birinin hedefleri karşılanmaktadır. Dolayısıyla insan kaynaklarının başarılı yönetimi, bir örgütün etkin işleyişinin anahtarlarından biridir. Hem özel sektör hem de kamu sektöründeki yöneticilerin, başarılı olmaları ve kuruluş hedeflerine ulaşabilmeleri için insan kaynakları yeteneklerinden faydalanmaları gerekmektedir. Bu nedenle iyi bir kuruluş, yetkin insanları bünyesine katmaya çalışmalıdır. Böylelikle kuruluşun hedeflerine ulaşması halinde, insan kaynaklarının en iyi şekilde motive edildiği ve iş tatmini yaratmak için uygun şekilde yönetildiği söylenebilmektedir. $\mathrm{Bu}$, bir kuruluşun mevcut ve gelecekteki insan kaynakları ihtiyaçlarını planlaması gerektiği anlamına gelmektedir. (Tandu, 2016, s.47)

En büyük sağlık hizmetleri iş güçlerinden birinde yapılan araştırmaya göre, tüm düzeylerdeki yöneticilerin insan kaynakları yönetimini etkili ve verimli bir şekilde geliştirilmesi ve konuşlandırılmasında oynadıkları hayati rolü ortaya koymuştur. Stratejik insan kaynakları yönetimi aracılığıyla, sağlık yöneticileri, çalışanların gelişimini kuruluşun ihtiyaçlarına göre ayarlayabilmelidir. Bu, üst yönetimin, iş gücü planlamasını, iş gücü modernizasyonunu ve iş gücü eğitimini ve geliştirmesini bütünleştiren yerleşik ve sürdürülebilir, kurumsal çapta bir iş gücü geliştirme stratejisine her zaman açık bir taahhütte bulunmasını gerektirir. (Walse ve Simth. 2011, s.349) Bu durum ile nepotik bir durumun ortaya çıkmayacağı ve insan kaynağının yöneltilmesinin liyakat esasına göre yapılacağının vurgusu belirtilmelidir.

Nepotizm, paydaşlar arasında da güvensizliğin oluşmasına sebep olduğu gibi, yetenekli yöneticilerin istihdamını önleyeceğinden, şirket entelektüel sermayeden yoksun kalacaktır. Bilindiği üzere bir örgüte rekabet avantajı sağlayan en önemli girdilerden biri de, "örgütün ne bildiğidir". P. F. Drucer (2005)'a göre entelektüel sermaye; "Pazar içerisinde şirkete rekabet avantajı sağlayan, şirkete değer katan kaynaklar" olarak tanımlanmıştır Şüphesiz, aile şirketlerini başarıya ulaştıran, rekabet avantajı sağlayan salt maddi varlıklar değildir. Aynı zamanda maddi olmayan varlıklardan olan entelektüel sermaye birikimi, örgüt performansında çoğaltan etkisi yaratacaktır. (Öztürk, 2008, s.464)

Sealy, (2010)'a göre liyakat; zenginlik, aile ilişkileri, sınıf ayrıcalığı, popülerlik gibi sosyal konum veya politik güç vb. özellikleri bertaraf ederek bunlar yerine işle ilgili yetenek ve vasıflara göre atama ve yerleştirmelerin yapıldığı ve sorumlulukların verildiği bir yönetim ve örgütlenme sistemidir. (Ramazan, 2019, s.41) Liyakat veya nepotizm adı altında yapılan tartışmalar aslında egemen sınıfın özelliklerini tanımlama çalışmalarıdır. (Şahin, 2016, s.240)

Stratejik insan kaynakları konusunda yapılan çalışmalara bakılacak olursa Grinold (1976), Martel ve Price (1981) ve Rao (1990) çağrı merkezlerinde iş gücünü yönetmek adına işgücü yönetimi modelleri geliştirler (Gass ve diğ., 1988) Tıp fakültesi bütçelerine (Brandeau vd., 1987; Lee vd., 1987) ve işgücünün çapraz eğitim ve esnekliği üzerinde çalışmalar yapıldı (Vairaktarakis ve Winch, 1999; Pinker and Shumsky, 2000). Bartholomew vd., (1991), Ernst vd., (2004) ve Turner vd., (2010), iş gücü / işgücü planlama modellerinin genel görünümünü sunarken, Boudreau vd., (2003) operasyonlar ve insan kaynakları yönetimi modelleri ve bu modellerle ilgili karmaşıklıklar arasında daha büyük bir arayüz ihtiyacı üzerinde durmuştur. Son zamanlarda 
yapılan işler, iş gücü sorunlarını operasyonel veya taktiksel zaman çerçevelerinde ele almaya devam etmiştir. Bard ve Wan (2008)'ın yapmış oldukları çalışma buna örnek teşkil etmektedir. Kısa zamanlı planlama üzerine odaklanma, aynı zamanda sağlık hizmetleri ve acil iş gücü planlamasına da etkili olmuştur (Fry vd., 2006; de Véricourt ve Jennings, 2011; Yankovic ve Green, 2011; Bienstock ve Zenteno, 2012). Gans ve Zhou'nun (2002) uzun vadeli iş gücü kapasite planlama modelleri, Ahn ve diğ. (2005) ve Song ve Huang (2008) çalışmalarıyla ilgilidir; Bununla birlikte, sağlık görevlilerini yönetmek için gerekli olan diğer bazı kararları almadan, personel istihdamı ve kalıcılığı üzerinde yoğunlaşmaktadırlar. (Çağatay, 2019, s. 99-100)

Bu çalışmada sağlık kurumlarında çalışmakta olan personelin liyakat esaslarına göre alınıp alınmadığını ortaya koymak istenmektedir. Çalışmayı gerçekleştirmek için sağlık kurumlarında çalışan personele sorular yöneltilerek cevaplar aranmıştır.

\section{Literatür}

\subsection{Stratejik İnsan Kaynakları Yönetimi}

Guest (1987) 'e göre İnsan Kaynakları Yönetimi (İKY) terimi, geleneksel personel yönetiminden (örgütün üyelerini ve ihtiyaçlarını yönetme süreci) daha stratejik bir yaklaşım geliştiren yeni bir yaklaşımdır (Abujudeh, 2019, s.139). Armstrong, (2014)'e göre İKY, iş hayatında hızla değişen bir uygulama alanı olup organizasyonların başarılarında kritik bir faktördür. Bir diğer ifade ile organizasyonun hedeflerini gerçekleştirebilmek için en değerli varlık olan insan faktörünün yönetilmesini içeren stratejik ve kapsamlı bir yaklaşımdır. (Kıdak vd. 2016, s.2)

Bir şirket için insan kaynağ olmadan, misyonu yerine getirmenin veya bir şirket içinde belirli bir vizyona ulaşmanın imkansız olmasıdır. Öte yandan sermaye teorisi, çalışanları yetkinliklerine göre değerlenebilecek varlıklar olarak görmektedir. Buna göre insan kaynakları bir şirketin en önemli sermayesidir çünkü pek çok şirket için insanlar önemli birer stratejik araçtır. Kuruluşlar için müşterilerle hayati temas başarının anahtarıdır. Bu anahtar da yetkin çalışandan geçer. Waterman (1994), İKY'nin, organizasyonun önemli bir rekabet avantajı kaynağı olduğunu kabul etmektedir. (Dumitrana, 2011, s.59)

IKKY'nin rolü, kuruluş türüne bakılmaksızın insan kaynakları departmanı ve yönetimi arasındaki ortaklıktır. Bu sebeple insan kaynakları departmanlarının çoğu benzer sorumluluklara sahiptir. Ancak insan kaynakları ve yönetim ortaklığı, birer sağlık kuruluşu olan hastanelerde benzersizdir, çünkü birçok hastane, farklı sorumlulukları ve farklı eğitim ihtiyaçları olan iki ayrı grubu denetleyen klinik yöneticilerin ve sağlık hizmetleri yöneticilerinin ikili idari yapısına sahiptir. Örneğin, klinik yöneticileri belirli bir klinik alanda eğitim veya deneyime sahip olmaları sebebiyle, diğer genel yöneticilere veya sağlık hizmetleri yöneticilerine göre daha spesifik sorumluluklara sahiptir. Örneğin, fizik tedavi müdürleri deneyimli fizyoterapistlerden, hemşire yöneticileri hemşirelik derecelerine sahip kişilerden oluşmaktadır. Diğer yandan çoğu sağlık hizmeti yöneticisinin, sağlık hizmetlerinde lisans veya yüksek lisans derecesi bulunmaktadır. (Niles, 2013, s.23) Ancak sağlık çalışanlarında oluşacak beklentilerin stratejik İKY uygulamaları yoluyla karşılanması halinde, bu durum sağlık çalışanlarının rolünden etkilenme, bu rolde kalma ve faaliyetlerini yürütme yönündeki davranışlarını etkileyecektir. (Bejtkovský, 2017, s. 1834)

Kuhlmann ve Larsen (2015, s. 1640) de Niles'in görüşlerini destekler nitelikte; hastane hizmetlerinde çalışan kişilerin çok farklı meslek gruplarından oluştuğunu, dolayısıyla bu durumun ortaya çıkan karmaşıklığ yönetmeyi zorlaştırdığını belirtmekte ve stratejik insan kaynakları yönetiminin önemini vurgulamaktadır. Gupta ve diğerleri, (2003, s. 9) ise, sağlık hizmetlerinin; doğrudan insan yaşamı ile ilişkili olması durumunun, çok farklı meslek grubunun uyum içerisinde çalışması gerekliliğinin, farklı meslek grupları arasında gerçekleşen karmaşık ilişkiler ve bu ilişkilerin yönetilmesi ihtiyacının sağlık hizmetlerinde İKY'e duyulan gereksinimi arttırdığına değinmişlerdir. (Kıdak vd. 2016, s. 3) İKY politika seçimlerini, arzu edilen insan 
kaynakları sonuçlarına etkili bir şekilde dönüştüren yönetim uygulamaları, uzaktan işgücü sürdürülebilirliğinin geliştirilmesi için hayati önem taşımaktadır. (Onnis, 2019, s. 21)

Çalışmada daha önce de ifade edildiği gibi insanlar, birçok şirketin yönetiminde stratejik bir aracı temsil etmektedir. Bir kuruluşta, farklı yaşlarda dolayısıyla farklı nesillerden ve farklı özelliklere sahip çalışanlar bulunmaktadır. Yararlılıkları yeteneklerine, niteliklerine ve tutumlarına bağlıdır (Hitka, 2018, s. 2759). Bununla ilgili olarak, Fleming ve McConnell (2014, s.45) da birer sağlık kuruluşu olan hastanelerde, tipik insan kaynakları departmanının tek kişilik bir operasyondan çok yönlü, karmaşık bir organizasyona dönüştüğünü belirtmektedir. Niles'a (2013) göre bu organizasyonun merkezinde bulunan sağlık çalışanları, bir hastanenin insan kaynaklarını meydana getirmekte ve en değerli varlığı olmaktadır. Bu sebeple başarılı olmak için, bir hastane sağlık çalışanlarının verimliliğini önemli bir hedef haline getirmelidir. Verimlilik düzeyi ise, çalışanların işlerinde gösterdikleri beceri düzeylerine ve hastane çalışanlarının iş becerilerinin yanı sıra memnuniyet düzeylerine de bağlı olarak değişebilmektedir. Bu noktada yüksek performanslı ve etkili bir işgücü geliştirmek için hastane, bir takım organizasyon alanlarında insan kaynakları yönetim girdilerini kullanmalıdır. Bu organizasyon alanları; yasal ve etik bir yönetim sisteminin kurulması, iş tasarımı ve iş analizi, işe alım ve seçim, sağlık kariyeri fırsatları, çalışanlara sağlanan faydaların dağılımı, çalışanların teşvik edilmesi ve çalışanların motivasyonu, örgütlü işgücü ile müzakereler, çalışanların işten çıkarılması, sağlık hizmetleri ve stratejik planlama şeklinde sıralanabilmektedir (Bejtkovský, 2017, s. 1834). Bu görüşü destekler nitelikte yüksek gelirli ülkelerde yapılan araştırmalar, bir örgütün stratejisine ve misyonuna uygun olan "birbirine bağlı insan kaynakları uygulamalarının" çalışanların performansını artırmada etkili olduğunu göstermektedir. (Dieleman, 2009, s. 8)

Sağlıkla ilgili insan kaynakları, kamu veya özel sağlık hizmetlerinde çalışmakta olan ve burada oluşan vaka müdahalelerinden sorumlu, farklı tipte klinik ve idari personel olarak tanımlanabilir. Sağlık sektörü reformundaki insan kaynakları aynı zamanda hizmetlerin kalitesini ve hasta memnuniyetini artırmaya çalışmaktadır. (Kabene vd. 2006, s. 1) Kanada Sağlık Bilgi Yönetimi Derneği 2007 yılından bu yana Kanada'daki sağlık iş gücünün geleceğini planlamak için yaptığı faaliyetleri içesinde, ana başlıklar olarak sağlık kurumlarında "sektör çalışması, stratejik planlama süreci ve stratejik insan kaynakları planlama" girişimlerinin olması gerektiğini ortaya koymuştur (Shepheard, 2011, s. 4).

Sağlık hizmetlerinin etkin bir şekilde sunulması insan kaynakları kısıtlamalarından da ciddi şekilde etkilenmektedir. Personel türleri, dağıtılma şekilleri ve personelin performansı şeklinde, sağlık personelleri arasında önemli endişeler yer almaktadır. Uygun insan kaynakları yönetimi (IKY) politikaları ve uygulamaları, insan kaynakları sonuçlarını ve dolayısıyla işgücü etkinliğini artırabilmekte ve bu da organizasyonel performansın iyileşmesine katkıda bulunmaktadır. IKKY politika ve uygulamalarının uygun sağlık hizmeti hedefleriyle uyumlu olduğu varsayıldığında, İKY iyileştirilmiş sağlık sonuçlarına yol açacaktır. Bunun yanında İKY "bir kuruluşun çalışanlarını yönetme ve gelişmelerine yardımcı olma şekli" olarak ifade edilecek olduğunda bu, önemli bir yönünün, personel ve diğer kaynaklar arasında bir denge sağlamak olan işi yapmak için, doğru sayıda ve türde personel alınmasını içermektedir. Sağlık kurumlarında özellikle personel maliyetleri genellikle toplam bütçenin\%60'ından fazlasını oluşturmaktadır. (Sohag vd. 2013, s.56)

Organizasyonlardaki insan kaynakları yönetimi, kariyer yönetimi ile ilgili birçok uygulamayı da içermektedir. Değişim ortamında, insan kaynakları uygulamalarına odaklanmanın iş sonuçları üzerinde büyük bir olumlu etkisi olabilir ve bunun sağlık hizmetleri için de geçerli olduğuna şüphe yoktur. Flanagan'ın (1997, s.188) ifade ettiği gibi, bir kuruluştaki personelin müşterilere iyi davranması isteniyorsa, öncelikle kuruluş personele iyi davranmalıdır". (Lammintakanen vd. 2002, s.322). Bu düşünceyi doğrular nitelikte kuruluşlar, şimdiye kadar başarılarının büyük ölçüde çalışanlarına bağlı olduğunu fark etmişlerdir (Gallo vd. 2019, s.18). Bu yüzden kuruluşlar, İKY uygulamalarını etkili ve verimli bir şekilde uygulanmasını sağlayacak şekilde planlamalı ve değerlendirmelidirler (Abujudeh, 2019, s. 143). 


\subsection{Liyakat}

Çalışan personelin çalışma düzenine kaynaklık eden ilkeler arasında "liyakat" öteden beri çok önemli bir yer işgal etmiştir. Sözcük olarak lâyık olma, yaraşırlık, uygunluk, yeterlilik, kifayet anlamlarını karşılayan liyakat; kurum hizmetlerinde görev alacak olan personelin görevin gerektirdiği niteliklere (eğitim, bilgi, beceri, görgü, kültür, yetenek, altyapı gibi) sahip olması gerektiğini ifade eder. (Acar, 2012, s. 32). Türk Dil Kurumuna göre Liyakat; Bir kimsenin, kendisine iş verilmeye uygunluk, yaraşırlık durumu, değim olarak tanımlanmıştır. (TDK, 2020)

Liyakat, kişinin gösterdiği performansı ile oluşturulmaktadır. Performanslar belirli bağlamlar için değer yaratır; performanslar ve liyakat kanıtı gerektiren grup arasında işlevsel bir ilişki vardır. Performanstaki değişim liyakat derecelerini belirler. Potansiyel performans esasına göre çıkarılabilir, ancak değerli olmak için liyakat kanıtı gerektiren grupla ilgili kriterlere göre iyi performans göstermelidir. (Hermanowicz, 2019, s.343)

Teoride, ayrıcalığa ve keyfi takdire yer vermediğine inanılan liyakat ilkesi, hukuk devleti ilkesinin, siyasal ve sosyal haklar düzeninin bir sonucu olarak kabul görmektedir. Ancak pratikte, liyakat ilkesine aykırı olarak görülen çelişkili uygulamalardan kaçınılmamakta, bu temel ilkenin esasları uygulamaya yansitılamamaktadır. (Yıldız, 2016, s. 173). Bu bakımdan kuruluşlarda, hizmete alımda görevin gerektirdiği niteliklerden başka hiçbir ayrım gözetilemeyeceği ilkesine mutlaka yeniden işlerlik kazandırılması gerekmektedir. Devlet, kamu hizmetleri görevlerine girmeyi, sınıflar içinde ilerleme ve yükselmeyi, görevin sona erdirilmesini liyakat sistemine dayandırmalı ve bu sistemi eşit imkanlarla uygulamalıdır. (Sezer, 2003, s. 192)

Aslan (2012)'a göre liyakat ilkesinin demokratik ve sosyal devlet olma hedefine odakl1 Türk Kamu Sistemimizin insan kaynakları yönetiminde uygulanması birçok değişik açıdan önemlidir. (Şahin, 2016, s.238)

\section{Yöntem}

$\mathrm{Bu}$ araştırmada ilişkisel bir tarama yöntemi kullanılmıştır. Bu yöntemde bağımlı ve bağımsız değişken arasındaki ilişki ortaya konmaktadır. Buna göre araştırmada, insan kaynakları yönetimi uygulamaları ve liyakat ilkelerine ilişkin görüşler arasındaki ilişkinin ortaya konması, bu araştırmayı ilişkisel modele yöneltmiştir. İlişkisel model ise tasarımı aşağıdaki gibidir.

Şekil 1. İlişkisel model

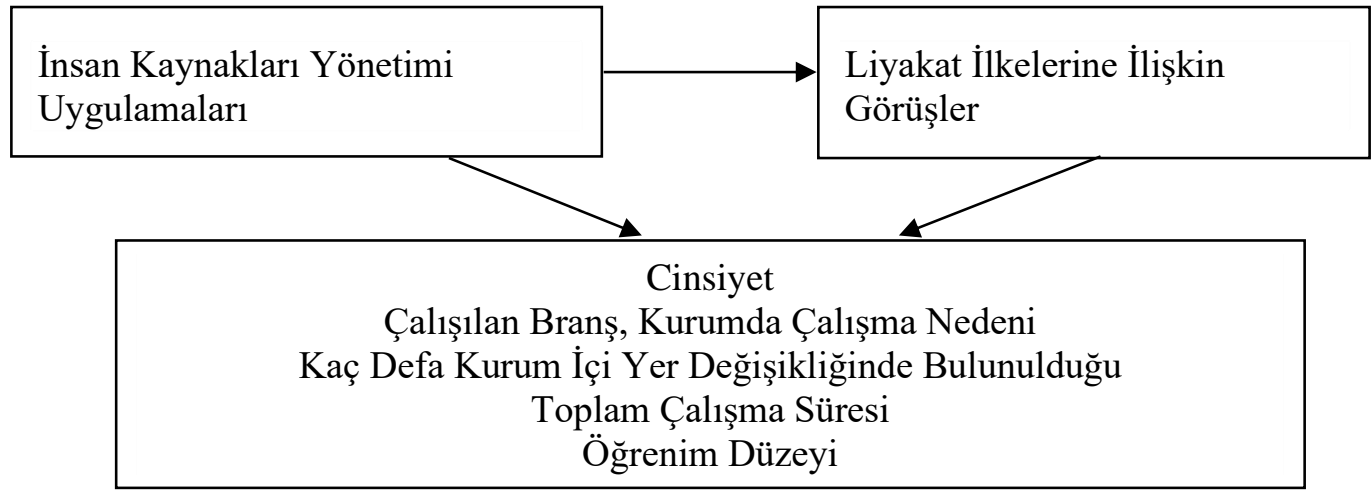

\subsection{Katılımcilar}

Çalışmada, verilerin elde edilmesi amacı ile anket yöntemine başvurulmuş olup anket soruları yüz yüze anket tekniğinden yararlanılarak katılımcılara ulaştırılmıştır. Anketlerin cevaplanması esnasında çalışanların isim ve soyad bilgileri talep edilmemiş, böylece gizlilik esasından hareketle ankette yer alan sorulara objektif yanıtlar verilmesi desteklenmiştir. Toplam 36 sorudan oluşan anket içerisinde üç bölüm yer almaktadır. Birinci bölüm katılımcıların demografik bilgilerine yöneliktir. Bu bölümde cinsiyet, çalışılan branş, kurumda çalışma nedeni, kaç defa kurum içi yer değişikliğinde bulunulduğu, toplam çalışma süresi ve öğrenim düzeyi ile 
ilgili sorular yer almaktadır. Araştırmada yer alan bu soruların temel kullanım amacı, ölçek içerisinde yer alan ifadelere göre farklılık oluşturup oluşturmadığının incelenmesidir.

\subsection{Veri Toplama Araçları}

Anket formunun ikinci bölümde İnsan Kaynakları Yönetimi Ölçeği bulunmaktadır. Bu kısımda toplam 15 ifade yer almakta olup, bu ifadeler kesinlikle katılmıyorum ile kesinlikle katılıyorum aralığı olan 5'li Likert ölçeği ile yapılmıştır. Araştırmada yapılan analiz sonucunda ölçek içerisinde yer alan ifadelerin güvenilirlik düzeyi 0,88 olarak tespit edilmiştir. Anket formunun üçüncü bölümünde ise Liyakat İlkeleri Ölçeği bulunmaktadır. Burada da toplam 15 ifade yer almaktadır. Söz konusu ifadelerin Cronbach's Alpha katsayılarına ilişkin yapılan çözümlemede $0,88^{\prime}$ lik düzeyde güvenilir olduğu tespit edilmiştir.

Ordu ilindeki özel ve kamu hastanelerinin çalışanlarına uygulanmıştır. Araştırma için TOGÜ Sosyal ve Beşeri Bilimler Araştırmaları Etik Kurulunun 23.06.2020 tarih E.29031 sayılı 09. Oturumunda KARAR 09.02 yazısı ile izni alınmıştır.

\section{3. İstatistiksel Analiz}

Araştırmada yer alan ölçekler Tunçer'in (2017) “Stratejik İnsan Kaynakları Yönetimi Ve Liyakat İlkesi: Ege Üniversitesi Tıp Fakültesi Örneği” adlı yüksek lisans tezinden alınmıştır. Uygulama sonucunda elde edilen verilerin çözümlenmesinde SPSS 26 paket programından yararlanılmıştır.

Araştırmanın, İKY uygulamaları ve liyakat ilkelerine ilişkin görüşler arasındaki ilişkiyi ortaya çıkarmaya yönelik yeterli ve güvenilir bilgiler toplayacak nitelikte olduğu düşünülmektedir. Ayrıca, bu araştırmaya katılanların ölçme aracındaki soruları samimi olarak cevaplandıracakları varsayılmaktadır. Bu araştırma katılımcılardan alınan cevaplarla sınırlıdır. Değerlendirme yöntemi olarak kullanılan anket soruları ile sınırlandırılmıştır.

\section{Bulgular}

\subsection{Normallik Analizi}

Araştırmada, anket yöntemi sonucu elde edilen verilerin normal dağılım gösterip göstermediği de test edilmiştir. Bu kısımda Kolmogorov-Smirnov ve Shapiro-Wilk değerlerinin .05 'ten büyük olmasına dikkat edilmiştir. Bu koşulun yerine geldiği durumlarda verilerin normal dağılıma sahip olduğu varsayılır.

Tablo 1. Normallik test sonuçları

\begin{tabular}{lccccccc}
\hline & \multicolumn{3}{c}{ Kolmogorov- } & \multicolumn{3}{c}{ Shapiro-Wilk } \\
\cline { 2 - 8 } & $\begin{array}{c}\text { İstatist } \\
\mathrm{ik}\end{array}$ & $\mathrm{df}$ & $\mathrm{p}$ & İstatistik & $\mathrm{df}$ & $\mathrm{p}$ \\
\hline İnsan Kaynakları &, 198 & 73 &, 000 &, 887 & 73 &, 000 \\
Yönetimi Uygulamaları & & & & & & \\
\hline Liyakat İlkeleri &, 152 & 73 &, 000 &, 898 & 73 &, 000 \\
\hline
\end{tabular}

Yukarıdaki tablodan anlaşılacağı üzere, anket uygulaması sonucu elde edilen verilerin normal dağılmadığı ortaya çıkmıştır.

\subsection{Katılımcılara Ait Genel Betimsel İstatistikler} almaktadır.

$\mathrm{Bu}$ kısımda katılımcıların temel demografik özelliklerinden elde edilen sonuçlar yer 
Tablo 2. Katılımcılara ait demografik özellikler

\begin{tabular}{|c|c|c|c|c|c|}
\hline \multicolumn{3}{|c|}{ Cinsiyet } & \multicolumn{3}{|c|}{$\begin{array}{l}\text { Kurumda İnsan Kaynağı Sağlama ve } \\
\text { Seçme Sürecini Kimin Yürüttüğü }\end{array}$} \\
\hline & $\mathrm{N}$ & $\%$ & & $\mathrm{~N}$ & $\%$ \\
\hline Kadın & 38 & 52,1 & Kurum Amiri & 63 & 86,3 \\
\hline Erkek & 35 & 47,9 & $\begin{array}{l}\text { İnsan Kaynakları } \\
\text { Departmanı }\end{array}$ & 10 & 13,7 \\
\hline Toplam & 73 & 100,0 & Toplam & 73 & 100,0 \\
\hline \multicolumn{3}{|c|}{ Yaş } & \multicolumn{3}{|c|}{ Fiili Olarak Yapılan İş } \\
\hline & $\mathrm{N}$ & $\%$ & & $\mathrm{~N}$ & $\%$ \\
\hline 25 yaş ve altı & 11 & 15,1 & $\begin{array}{l}\text { Atamam ne ise o iş } \\
\text { tanımımda ki kendi } \\
\text { işimi yapıyorum }\end{array}$ & 66 & 90,4 \\
\hline $\begin{array}{l}26-35 \text { yaş } \\
\text { aras1 }\end{array}$ & 33 & 45,2 & $\begin{array}{l}\text { Atamam ne ise o iş } \\
\text { tanımımda ki kendi } \\
\text { işimi yapmıyorum }\end{array}$ & 7 & 9,6 \\
\hline \multicolumn{2}{|l|}{$36-45$ yaş } & 19,2 & \multirow[b]{4}{*}{ Toplam } & & \\
\hline $\begin{array}{l}46-55 \text { yaş } \\
\text { aras1 }\end{array}$ & 10 & 13,7 & & & \\
\hline 55 ve üzeri & 5 & 6,8 & & & \\
\hline Toplam & 73 & 100,0 & & 73 & 100,0 \\
\hline \multicolumn{3}{|c|}{ Öğrenim Düzeyi } & \multicolumn{3}{|c|}{ Toplam Çalışma Süresi } \\
\hline & $\mathrm{N}$ & $\%$ & & $\mathrm{~N}$ & $\%$ \\
\hline Lise & 12 & 16,4 & $1-4$ y1l & 18 & 24,7 \\
\hline Önlisans & 27 & 37,0 & $5-14$ y1l & 34 & 46,6 \\
\hline Lisans & 33 & 45,2 & $15-24$ y1l & 13 & 17,8 \\
\hline Lisansüstü & 1 & 1,4 & 25 y1ldan fazla & 8 & 11,0 \\
\hline Toplam & 73 & 100,0 & Toplam & 73 & 100,0 \\
\hline \multicolumn{3}{|c|}{ Hangi Kadroda Çalışıldığ 1} & \multicolumn{3}{|c|}{$\begin{array}{c}\text { Kaç Defa Kurum İçi Yer Değişikliğinde } \\
\text { Bulunulduğu }\end{array}$} \\
\hline & $\mathrm{N}$ & $\%$ & & $\mathrm{~N}$ & $\%$ \\
\hline $\begin{array}{l}\text { 657 Devlet } \\
\text { Memuru }\end{array}$ & 47 & 64,4 & $\begin{array}{l}\text { Hep aynı yerde } \\
\text { çalıștım }\end{array}$ & 43 & 58,9 \\
\hline İşçi & 2 & 2,7 & $\begin{array}{l}2-5 \text { kez yer } \\
\text { değiştirdim }\end{array}$ & 19 & 26,0 \\
\hline Diğer & 24 & 32,9 & $\begin{array}{l}6 \text { ve üzeri kez yer } \\
\text { değiştirdim }\end{array}$ & 11 & 15,1 \\
\hline Toplam & 73 & 100,0 & Toplam & 73 & 100,0 \\
\hline \multicolumn{3}{|c|}{ Çalışılan Branş } & \multicolumn{3}{|c|}{ Kurumda Çalışma Nedeni } \\
\hline & $\mathrm{N}$ & $\%$ & & $\mathrm{~N}$ & $\%$ \\
\hline $\begin{array}{l}\text { Sağlik } \\
\text { Teknisyeni }\end{array}$ & 33 & 45,2 & İş Güvencesi & 14 & 19,2 \\
\hline İdari Personel & 12 & 16,4 & $\begin{array}{l}\text { Yaptığım İşin } \\
\text { Niteliği }\end{array}$ & 38 & 52,1 \\
\hline Büro Memuru & 12 & 16,4 & $\begin{array}{l}\text { Fiziksel Çalışma } \\
\text { Ortamı }\end{array}$ & 11 & 15,1 \\
\hline Sekreter & 16 & 21,9 & Kurumun Prestiji & 10 & 13,7 \\
\hline Toplam & 73 & 100,0 & Toplam & 73 & 100,0 \\
\hline
\end{tabular}


Tablo 2'ye bakıldığında katılımcıların \%52,1'inin kadın; \%47,9'unun ise erkek olduğu ortaya çıkmıştır. Bunun yanında katılımcıların büyük çoğunluğunun 26-35 yaş arasında olduğu; Ataması ne ise o iş tanımındaki işi yaptı̆̆ı; \%45,2 oranında katılımeı branşının sağlık teknisyenliği olduğu; kurumda “yaptığı işin niteliğinden” ötürü çalıştığı ve 657 Sayılı Kanun’a tabi devlet memuru pozisyonunda olduğu ortaya çıkmıştır.

\section{3. İnsan Kaynakları Yönetimi Ölçeğine Yönelik Elde Edilen Betimsel İstatistikler}

Araştırmanın bu kısmında İnsan Kaynakları Yönetimi Ölçeği içerisinde yer alan ifadelere katılımcıların verdikleri cevaplardan elde edilen veriler betimleyici analiz ile incelenmiş olup raporlanmıştır. Burada her bir ifade için katılımcı sayıları, yüzde dağılımları ve bu ifadelerin ortalama ve standart sapma değerlerine yer verilmiştir.

Tablo 3. İnsan kaynakları yönetimi ölçek ifadelerine yönelik elde edilen sonuçlar

\begin{tabular}{|c|c|c|}
\hline & $\bar{X}$ & SS \\
\hline $\begin{array}{l}\text { Hastanemizde sağlık personeline yeni görevler verilirken, işi ve görevi } \\
\text { tanıtıcı bilgiler verilir (görev tanımları, kariyer, sosyal olanaklar vb.) ve } \\
\text { yeni görev yerinde uyulması gereken kurallar yazılı olarak personele } \\
\text { iletilir. }\end{array}$ & 4,53 & ,929 \\
\hline $\begin{array}{l}\text { Yeni bir göreve başlarken işe alıştırma (oryantasyon) eğitimine tabi } \\
\text { tutuldum. }\end{array}$ & 4,41 & ,940 \\
\hline $\begin{array}{l}\text { Sizden daha kıdemli ya da yeni işe başlayan meslektaşlarımla } \\
\text { farklılıklarım vardır. }\end{array}$ & 4,15 & ,981 \\
\hline $\begin{array}{l}\text { İnsan Kaynakları Biriminin bana ait güçlü-zayıf yönleri, firsatları-tehditleri } \\
\text { bildiğini düşünüyorum }\end{array}$ & 3,70 & $\begin{array}{c}1,19 \\
8\end{array}$ \\
\hline $\begin{array}{l}\text { Personelin rızası olmadan yapılan yer değişikliklerinde, yıldırma ve } \\
\text { yaptırım amacıyla temposu yoğun olan servislere (acil servis gibi) } \\
\text { görevlendirme yapılmaktadır. }\end{array}$ & 4,29 & ,993 \\
\hline $\begin{array}{l}\text { Hastanemizde yer değişiklikleri yapılırken ya da yeni personel alımında } \\
\text { mevcut personelin tavsiyeleri dikkate alınır. }\end{array}$ & 2,96 & $\begin{array}{c}1,36 \\
9\end{array}$ \\
\hline $\begin{array}{l}\text { Hastanemizde devamsızlık, hastalık, kaza, izin vb. gibi durumlarda } \\
\text { doğabilecek işgücü kaybını giderecek sayıda sağlık personeli mevcuttur. }\end{array}$ & 3,81 & $\begin{array}{c}1,41 \\
1\end{array}$ \\
\hline $\begin{array}{l}\text { İş ortamında kişisel önyargılar ve düşünceler, sağlık personelinin bireysel } \\
\text { performansını etkiler. }\end{array}$ & 4,44 & ,986 \\
\hline $\begin{array}{l}\text { İnsan Kaynakları Yönetimi ve Planlamasının özel bir uzmanlık alanı } \\
\text { olduğunu düşünüyorum. }\end{array}$ & 3,70 & $\begin{array}{c}1,32 \\
0\end{array}$ \\
\hline Çalışma yerleri belirlenirken doğru işe doğru eleman politikası uygulanır. & 3,56 & $\begin{array}{c}1,63 \\
3\end{array}$ \\
\hline $\begin{array}{l}\text { Yoğun iş temposu nedeniyle yetiştiremediğim işler, performansımı } \\
\text { düşürmektedir. }\end{array}$ & 3,93 & $\begin{array}{c}1,57 \\
5\end{array}$ \\
\hline Çalıştığım bölümde yenilikçi fikir ve önerilere firsat verilmektedir. & 3,60 & $\begin{array}{c}1,38 \\
2\end{array}$ \\
\hline $\begin{array}{l}\text { Hastanemizde çalışanların kendilerini geliştirmeleri için uygun ortam } \\
\text { sağlanmaktadır. }\end{array}$ & 4,04 & $\begin{array}{c}1,31 \\
7\end{array}$ \\
\hline Sadece işimin gerektirdiği işlerle meşgul oluyorum & 4,04 & $\begin{array}{c}1,26 \\
3\end{array}$ \\
\hline Hastanemizdeki idari ve destek personelin sayıs1 yeterli ve kalitelidir. & 3,62 & $\begin{array}{c}1,49 \\
7\end{array}$ \\
\hline Genel Toplam & 3,92 &, 783 \\
\hline
\end{tabular}

Tablo 3 incelendiğinde katılımcıların İnsan Kaynakları Yönetimi uygulamalarına ilişkin görüşlerinin ortaya konması için oluşturulan ölçek ifadelerine, katılımcıların tümünün cevap verdiği görülmüsstür. Benzer şekilde, Tablo 3'de katılımcıların en yüksek değerli ortalamayı 
"Hastanemizde sağlık personeline yeni görevler verilirken, işi ve görevi tanıtıcı bilgiler verilir (görev tanımları, kariyer, sosyal olanaklar vb.) ve yeni görev yerinde uyulması gereken kurallar yazılı olarak personele iletilir.” ifadeleri ile sağladığı ortaya çıkmıştır. Bu kısımda ayrıca katılımcıların, en düşük düzeyli ortalamayı ise "Hastanemizde yer değişiklikleri yapılırken ya da yeni personel alımında mevcut personelin tavsiyeleri dikkate alınır." ifadesi ile sağladığı ortaya çıkmıştır.

\subsection{Liyakat İlkeleri Ölçeğine Yönelik Elde Edilen Betimsel İstatistikler}

Araştırmanın bu kısmında Liyakat İlkeleri Ölçeği içerisinde yer alan ifadelere katılımcıların verdikleri cevaplardan elde edilen veriler betimleyici analiz ile incelenmiş olup raporlanmıştır. Burada da her bir ifade için katılımcı sayıları, yüzde dağılımları ve bu ifadelerin ortalama ve standart sapma değerlerine yer verilmiştir.

Tablo 4. Liyakat ilkeleri ölçek ifadelerine yönelik elde edilen sonuçlar

\begin{tabular}{|c|c|c|}
\hline & $\overline{\mathrm{X}}$ & SS \\
\hline Aldığım eğitim ile fiili olarak yaptığım iş birbiri ile uyumludur. & 4,64 & ,734 \\
\hline $\begin{array}{l}\text { Benim için görevde yükselme konusunda liyakat ve yeterlilik } \\
\text { önemlidir. }\end{array}$ & 3,97 &, 833 \\
\hline $\begin{array}{l}\text { Benim için görevde yükselme konusunda liyakat yerine mesleki bilgi } \\
\text { birikim, hizmet süresi ve deneyim önemlidir. }\end{array}$ & 4,47 & ,783 \\
\hline $\begin{array}{l}\text { Hastanemizde personel planlaması yapılırken liyakat ilkelerine } \\
\text { uyulmaktadır. }\end{array}$ & 3,49 & 1,617 \\
\hline $\begin{array}{l}\text { Belirli bir alanda uzun yıllar çalışmış olmak, o alanda (yükselmek, bir } \\
\text { üst kadroya geçmek) yönetim görevi üstlenmek için önemlidir. }\end{array}$ & 3,52 & 1,345 \\
\hline $\begin{array}{l}\text { Çalışma alanım da yeterli bilgiye sahip olmasam da, üst yönetim } \\
\text { tarafından bir üst göreve getirilsem bundan hoşnut olurum. }\end{array}$ & 3,30 & 1,277 \\
\hline $\begin{array}{l}\text { Benim için görevde yükselme konusunda üst yönetimle iyi ilişkiler, } \\
\text { iletişim ve olumlu referans daha üst kademelere gelmek için } \\
\text { önemlidir. }\end{array}$ & 4,14 & 1,170 \\
\hline $\begin{array}{l}\text { Çalıştığım kurumda idari görevlere seçilme/atama ve personelin } \\
\text { yükseltilmesi ile ilgili ölçüler açık ve nettir. }\end{array}$ & 3,66 & 1,397 \\
\hline $\begin{array}{l}\text { Yöneticim bana, kendi işimle ilgili bağımsız karar verme yetkisi } \\
\text { tanır. }\end{array}$ & 3,16 & 1,756 \\
\hline Yaptığım işin sonunda takdir edilirim, ödüllendirilirim. & 3,03 & 1,833 \\
\hline $\begin{array}{l}\text { Hastanemizde çalışan idari personelin unvanları ile eğitimleri } \\
\text { birbiriyle uyumludur. }\end{array}$ & 3,60 & 1,460 \\
\hline $\begin{array}{l}\text { Personel temininde en etkili yöntemin merkezi sistemle sinav yapmak } \\
\text { olduğunu düşünüyorum }\end{array}$ & 3,82 & 1,171 \\
\hline $\begin{array}{l}\text { Personel seçme, atama ve yükseltme faaliyetlerinin, uzman bir ekip } \\
\text { tarafından oluşturulmuş bir komisyonca (liyakat komisyonu gibi) } \\
\text { yapılmasını isterim. }\end{array}$ & 4,14 & ,769 \\
\hline Yaptığım iş bulunduğum bölüm için faydalıdır. & 4,66 &, 853 \\
\hline Bulunduğum pozisyonda çalışmaktan memnunum. & 4,52 & ,669 \\
\hline Genel Toplam & 3,87 & ,751 \\
\hline
\end{tabular}

Tablo 4 incelendiğinde katılımcıların Liyakat İlkelerine ilişkin görüşlerinin ortaya konması için oluşturulan ölçek ifadelerine, katılımcıların tümünün cevap verdiği görülmüştür. Benzer şekilde, Tablo 4'te katılımcıların en yüksek değerli ortalamay1 "Yaptığım iş bulunduğum bölüm için faydalıdır." ifadesi ile en düşük ortalamayı ise "Yaptığım işin sonunda takdir edilirim, ödüllendirilirim." ifadesi ile sağladığı ortaya çıkmıştır. 


\subsection{Hipotezlerin Test Edilmesi}

Araştırmanın bu kısmında, İKY uygulamaları ve liyakat ilkelerine ilişkin görüşler arasında anlamlı bir ilişki olup olmadığının sonuçları yer almaktadır. Bu kısımda ayrıca, İKY uygulamaları ve liyakat ilkelerine ilişkin görüşler ile "cinsiyet, çalışılan branş, kurumda çalışma nedeni, kaç defa kurum içi yer değişikliğinde bulunulduğu, toplam çalışma süresi ve öğrenim düzeyi” değişkenleri arasında anlamlı bir farklılık olup olmadığının sonuçları yer almaktadır. Buna göre insan kaynakları yönetimi uygulamaları ve liyakat ilkelerine ilişkin görüşler arasındaki ilişkinin tespit edilmesinde korelasyon analizine başvurulmuştur. Bunun yanında katılımcıların insan kaynakları yönetimi uygulamaları ve liyakat ilkelerine ilişkin görüşlerinin karşılaştırılmasında, iki seçenekli sorular için Mann-Whitney U Testi; ikiden fazla seçeneğe sahip sorularda Kruskal-Wallis $\mathrm{H}$ testi uygulanmıştır. Araştırmada kullanılan Mann-Whitney U ve Kruskal-Wallis $\mathrm{H}$ testinin değerlendirilmesinde anlamlılık düzeyi 0.05 olarak kabul edilmiştir.

Tablo 5. İnsan kaynakları yönetimi uygulamaları ve liyakat ilkelerine ilişkin görüşler arasındaki ilişkinin korelasyon analizi sonuçları

\begin{tabular}{|c|c|c|c|c|}
\hline & & & Personel & Liyakat \\
\hline \multirow{6}{*}{ Spearman's rho } & \multirow{3}{*}{ Personel } & $\mathrm{r}$ & 1,000 & ,902** \\
\hline & & $\mathrm{p}$ & &, 000 \\
\hline & & $\mathrm{N}$ & 73 & 73 \\
\hline & \multirow{3}{*}{ Liyakat } & $\mathrm{r}$ &, $902 * *$ & 1,000 \\
\hline & & $\mathrm{p}$ &, 000 & . \\
\hline & & $\mathrm{N}$ & 73 & 73 \\
\hline
\end{tabular}

Tablo 5 incelendiğinde katılımcıların IKKY uygulamalarına yönelik görüşleri ile liyakat ilkelerine yönelik görüşleri arasında anlamlı bir iliş̧i olduğu ortaya çıkmıştır. Bu ilişkinin yönüne bakıldığında ise pozitif yönde olduğu tespit edilmiştir.

Tablo 6. İnsan kaynakları yönetimi uygulamaları ve liyakat ilkelerine ilişkin görüşlerin cinsiyet değișkenine göre karşılaştırılması

\begin{tabular}{|c|c|c|c|c|c|c|}
\hline & $\begin{array}{l}\text { Cinsiy } \\
\text { et }\end{array}$ & $\mathrm{N}$ & $\begin{array}{l}\text { Sirali } \\
\text { Ortalama }\end{array}$ & $\begin{array}{l}\text { Siralar } \\
\text { Toplamı }\end{array}$ & $\begin{array}{l}\text { Mann-Whitney } \\
\text { U }\end{array}$ & $\mathrm{p}$ \\
\hline \multirow[t]{3}{*}{ Personel } & Kadın & 38 & 39,22 & 1490,50 & \multirow{3}{*}{580,500} & \multirow{3}{*}{,35 } \\
\hline & Erkek & 35 & 34,59 & 1210,50 & & \\
\hline & Toplam & 73 & & & & \\
\hline \multirow[t]{3}{*}{ Liyakat } & Kadın & 38 & 38,43 & 1460,50 & \multirow{3}{*}{610,500} & \multirow{3}{*}{, 55} \\
\hline & Erkek & 35 & 35,44 & 1240,50 & & \\
\hline & Toplam & 73 & & & & \\
\hline
\end{tabular}

Cinsiyet değişkeni ile İKY uygulamaları ve liyakat ilkelerine yönelik görüşlerin MannWhitney U testi sonuçlarında 0.05 düzeyinde anlamlı bir farklılık olmadığı ortaya çıkmıştır. 
Tablo 7. İnsan kaynakları yönetimi uygulamaları ve liyakat ilkelerine ilişkin görüşlerin çalışılan branş değişkenine göre karşılaştırılması

\begin{tabular}{|c|c|c|c|c|c|}
\hline & Çalışılan Branş & $\mathrm{N}$ & $\begin{array}{l}\text { Siral1 } \\
\text { Ortalama } \\
\end{array}$ & $\begin{array}{l}\text { Kruskal-Wallis } \\
\mathrm{H}\end{array}$ & $\mathrm{p}$ \\
\hline \multirow{5}{*}{ Personel } & $\begin{array}{l}\text { Sağlık } \\
\text { Teknisyeni }\end{array}$ & 33 & 38,30 & \multirow{5}{*}{9,431} & \multirow{5}{*}{,02 } \\
\hline & İdari Personel & 12 & 32,33 & & \\
\hline & Büro Memuru & 12 & 23,83 & & \\
\hline & Sekreter & 16 & 47,69 & & \\
\hline & Toplam & 73 & & & \\
\hline \multirow{5}{*}{ Liyakat } & $\begin{array}{l}\text { Sağlik } \\
\text { Teknisyeni }\end{array}$ & 33 & 37,20 & \multirow{5}{*}{9,271} & \multirow{5}{*}{,03 } \\
\hline & İdari Personel & 12 & 33,08 & & \\
\hline & Büro Memuru & 12 & 24,79 & & \\
\hline & Sekreter & 16 & 48,69 & & \\
\hline & Toplam & 73 & & & \\
\hline
\end{tabular}

Çalışılan branş değişkeni ile İKY uygulamaları ve liyakat ilkelerine yönelik görüşlerin Kruskal-Wallis H testi sonuçlarında 0.05 düzeyinde anlamlı bir farklılık olduğu ortaya çıkmıştır. Bu kısımda ortaya çıkan farklılığın hangi gruplar arasında olduğunun tespiti amaciyla çoklu karşılaştırma test yöntemlerinden katılımcı sayılarının birbirinden farklı sayıda olduğu durumlarda yararlanılan Hochberg testi kullanılmış olup teste ilişkin sonuçlar aşağıdaki tabloda gösterilmiştir.

Tablo 8. Çalışılan branş değişkenine göre insan kaynakları yönetimi uygulamaları ve liyakat ilkelerine ilişkin görüşlerinin çoklu karşılaştırma sonuçları

\begin{tabular}{llccc}
\hline Hochberg & Çalışılan Branş & Alt Gruplar & $\begin{array}{c}\text { Ortalamalar } \\
\text { Fark1 }\end{array}$ & $\mathrm{p}$ \\
\hline Personel & Sekreter & Büro Memuru &, 88472 &, 016 \\
\hline Liyakat & Sekreter & Büro Memuru &, 81111 &, 026
\end{tabular}

Çalışılan branş değişkenine göre; sekreter olarak çalışanların IKKY uygulamaları ve liyakat ilkelerine yönelik görüşleri ile büro memuru olarak çalışanların görüşleri arasında anlamlı bir farklılık olduğu ortaya çıkmıştır.

Tablo 9. İnsan kaynakları yönetimi uygulamaları ve liyakat ilkelerine ilişkin görüşlerin kurumda çalışma nedeni değişkenine göre karşılaştırılması

\begin{tabular}{|c|c|c|c|c|c|}
\hline & $\begin{array}{l}\text { Kurumda Çalışma } \\
\text { Nedeni }\end{array}$ & $\mathrm{N}$ & $\begin{array}{c}\text { Siralı } \\
\text { Ortalama }\end{array}$ & Kruskal-Wallis H & $\mathrm{p}$ \\
\hline \multirow{5}{*}{ Personel } & İş Güvencesi & 14 & 22,75 & \multirow[t]{5}{*}{9,024} & \multirow[t]{5}{*}{,03 } \\
\hline & Yaptığım İșin Niteliği & 38 & 39,49 & & \\
\hline & Fiziksel Calısma Ortamı & 11 & 37,64 & & \\
\hline & Kurumun Prestiji & 10 & 46,80 & & \\
\hline & Toplam & 73 & & & \\
\hline \multirow{5}{*}{ Liyakat } & İş Güvencesi & 14 & 22,29 & \multirow[t]{5}{*}{9,019} & \multirow[t]{5}{*}{,03 } \\
\hline & Yaptığım İşin Niteliği & 38 & 39,30 & & \\
\hline & Fiziksel Çalışma Ortamı & 11 & 40,14 & & \\
\hline & Kurumun Prestiji & 10 & 45,40 & & \\
\hline & Toplam & 73 & & & \\
\hline
\end{tabular}

Kurumda Çalışma Nedeni değişkeni ile İKY uygulamaları ve liyakat ilkelerine yönelik görüşlerin Kruskal-Wallis $\mathrm{H}$ testi sonuçlarında 0.05 düzeyinde anlamlı bir farklılık olduğu ortaya 
çıkmıştır. Bu kısımda ortaya çıkan farklılı̆̆ın hangi gruplar arasında olduğunun tespiti amacıyla çoklu karşılaştırma test yöntemlerinden katılımcı sayılarının birbirinden farklı sayıda olduğu durumda yararlanılan Hochberg testi kullanılmış olup teste ilişkin sonuçlar aşağıdaki tabloda gösterilmiştir.

Tablo 10. Kurumda çalışma nedeni değişkenine göre insan kaynakları yönetimi uygulamaları ve liyakat ilkelerine ilişkin görüşlerinin karşılaştırılması

\begin{tabular}{lllll}
\hline \multirow{2}{*}{ Hochberg } & $\begin{array}{c}\text { Kurumda } \\
\text { Çalışma } \\
\text { Nedeni }\end{array}$ & \multicolumn{1}{c}{ Alt Gruplar } & $\begin{array}{c}\text { Ortalamalar } \\
\text { Fark1 }\end{array}$ & $\mathrm{p}$ \\
\hline \multirow{2}{*}{ Personel } & \multirow{2}{*}{ İş̧ Güvencesi } & $\begin{array}{l}\text { Yaptı̆̆ım İşin } \\
\text { Niteliği }\end{array}$ &, 66717 &, 032 \\
\cline { 3 - 5 } & Kurumun Prestiji &, 90190 &, 027 \\
\hline Liyakat & İş Güvencesi & Kurumun Prestiji &, 84000 &, 036 \\
\hline
\end{tabular}

Kurumda çalışma nedeni değişkenine göre; iş güvencesinden ötürü kurumda çalışanların IKKY uygulamalarına yönelik görüşleri ile yaptığı işin niteliği ve kurumun prestijinden ötürü kurumda çalışanların görüşleri arasında anlamlı bir farklılık olduğu ortaya çıkmıştır. Bununla beraber, iş güvencesinden ötürü kurumda çalışanların liyakat ilkelerine yönelik görüşleri ile kurumun prestijinden ötürü kurumda çalışanların görüşleri arasında anlamlı bir farklılık olduğu ortaya çıkmıştır.

Tablo 11. İnsan kaynakları yönetimi uygulamaları ve liyakat ilkelerine ilişkin görüşlerin kaç defa kurum içi yer değişikliğinde bulunulduğu değişkenine göre karşılaştırılması

\begin{tabular}{|c|c|c|c|c|c|}
\hline & $\begin{array}{l}\text { Kaç Defa Kurum İçi Yer } \\
\text { Değişikliğinde } \\
\text { Bulunulduğu }\end{array}$ & $\mathrm{N}$ & $\begin{array}{c}\text { Sirali } \\
\text { Ortalama }\end{array}$ & $\begin{array}{c}\text { Kruskal-Wallis } \\
\mathrm{H}\end{array}$ & $\mathrm{p}$ \\
\hline \multirow[t]{4}{*}{ Personel } & Hep aynı yerde çalıștım & 43 & 46,41 & \multirow{4}{*}{23,138} & \multirow{4}{*}{, 00} \\
\hline & 2-5 kez yer değiştirdim & 19 & 18,89 & & \\
\hline & $\begin{array}{l}6 \text { ve üzeri kez yer } \\
\text { değistirdim }\end{array}$ & 11 & 31,50 & & \\
\hline & Toplam & 73 & & & \\
\hline \multirow[t]{4}{*}{ Liyakat } & Hep aynı yerde çalıştım & 43 & 47,57 & \multirow{4}{*}{27,608} & \multirow{4}{*}{00} \\
\hline & 2-5 kez yer değiştirdim & 19 & 18,18 & & \\
\hline & $\begin{array}{l}6 \text { ve üzeri kez yer } \\
\text { değistirdim }\end{array}$ & 11 & 28,18 & & \\
\hline & Toplam & 73 & & & \\
\hline
\end{tabular}

Kaç defa kurum içi yer değişikliğinde bulunulduğu değişkeni ile İKY uygulamaları ve liyakat ilkelerine yönelik görüşlerin Kruskal-Wallis $\mathrm{H}$ testi sonuçlarında 0.05 düzeyinde anlamlı bir farklı1ık olduğu ortaya çıkmıştır. Bu kısımda ortaya çıkan farklı1ığın hangi gruplar arasında olduğunun tespiti amacıyla çoklu karşılaştırma test yöntemlerinden katılımcı sayılarının birbirinden farklı sayıda olduğu durumda yararlanılan Hochberg testi kullanılmış olup teste ilişkin sonuçlar aşağıdaki tabloda gösterilmiştir. 
Tablo 12. Kaç defa kurum içi yer değişikliğinde bulunulduğu değişkenine göre insan kaynakları yönetimi uygulamaları ve liyakat ilkelerine ilişkin görüşlerinin çoklu karşılaştırma sonuçları

\begin{tabular}{|c|c|c|c|c|}
\hline Hochberg & $\begin{array}{l}\text { Kaç Defa Kurum İçi } \\
\text { Yer Değişikliğginde } \\
\text { Bulunulduğu }\end{array}$ & Alt Gruplar & $\begin{array}{c}\text { Ortalamalar } \\
\text { Fark1 }\end{array}$ & $\mathrm{p}$ \\
\hline
\end{tabular}

\begin{tabular}{lllll}
\hline \multirow{2}{*}{ Personel } & Hep aynı yerde çalıştım & $\begin{array}{l}\text { 2-5 kez yer } \\
\text { değiştirdim }\end{array}$ & 1,05483 &, 000 \\
\cline { 3 - 5 } & $\begin{array}{l}\text { 6 ve üzeri kez yer } \\
\text { değiştirdim }\end{array}$ &, 64144 &, 012 \\
\hline \multirow{2}{*}{ Liyakat } & Hep aynı yerde çalıştım & $\begin{array}{l}2-5 \text { kez yer } \\
\text { değiştirdim }\end{array}$ & 1,06863 &, 000 \\
\cline { 3 - 5 } & $\begin{array}{l}\text { 6 ve üzeri kez yer } \\
\text { değiştirdim }\end{array}$ &, 74390 &, 001 \\
\hline
\end{tabular}

Kurum içinde kaç defa yer değişikliğinde bulunulduğu değişkenine göre; hep aynı yerde çalışanların IKKY uygulamaları ve liyakat ilkelerine yönelik görüşleri ile 2-5 kez ve 6 ve üzeri kez yer değiştirenlerin görüşleri arasında anlamlı bir farklılık olduğu ortaya çıkmıştır.

Tablo 13. İnsan kaynakları yönetimi uygulamaları ve liyakat ilkelerine ilişkin görüşlerin toplam çalışma süresi değişkenine göre karşılaştırılması

\begin{tabular}{|c|c|c|c|c|c|}
\hline & $\begin{array}{l}\text { Toplam Çalışma } \\
\text { Süresi }\end{array}$ & $\mathrm{N}$ & $\begin{array}{c}\text { Siralı } \\
\text { Ortalama }\end{array}$ & $\begin{array}{c}\text { Kruskal-Wallis } \\
\mathrm{H}\end{array}$ & $\mathrm{p}$ \\
\hline \multirow{5}{*}{ Personel } & $1-4$ y1l & 18 & 50,58 & \multirow{5}{*}{15,160} & \multirow{5}{*}{,00 } \\
\hline & $5-14$ y1l & 34 & 37,68 & & \\
\hline & $15-24$ y1l & 13 & 23,08 & & \\
\hline & 25 yildan fazla & 8 & 26,19 & & \\
\hline & Toplam & 73 & & & \\
\hline \multirow{5}{*}{ Liyakat } & $1-4$ y1l & 18 & 52,83 & \multirow{5}{*}{20,734} & \multirow{5}{*}{00} \\
\hline & $5-14$ y1l & 34 & 37,81 & & \\
\hline & $15-24$ y1l & 13 & 20,27 & & \\
\hline & 25 yıldan fazla & 8 & 25,13 & & \\
\hline & Toplam & 73 & & & \\
\hline
\end{tabular}

Toplam çalışma süresi değişkeni ile İKY uygulamaları ve liyakat ilkelerine yönelik görüşlerin Kruskal-Wallis $\mathrm{H}$ testi sonuçlarında 0.05 düzeyinde anlamlı bir farklılık olduğu ortaya çıkmıştır. Bu kısımda ortaya çıkan farklılığın hangi gruplar arasında olduğunun tespiti amacıyla çoklu karşılaştırma test yöntemlerinden katılımcı sayılarının birbirinden farklı sayıda olduğu durumda yararlanılan Hochberg testi kullanılmış olup teste ilişkin sonuçlar aşağıdaki tabloda gösterilmiştir.

Tablo 14. Toplam çalışma süresi değişkenine göre insan kaynakları yönetimi uygulamaları ve liyakat ilkelerine ilişkin görüşlerinin çoklu karşılaş̧ırma sonuçları

\begin{tabular}{|c|c|c|c|c|}
\hline Hochberg & $\begin{array}{l}\text { Toplam Çalışma } \\
\text { Süresi }\end{array}$ & Alt Gruplar & $\begin{array}{c}\text { Ortalamalar } \\
\text { Fark1 }\end{array}$ & $\mathrm{p}$ \\
\hline \multirow[t]{2}{*}{ Personel } & \multirow[t]{2}{*}{$1-4$ y1l } & $15-24 \mathrm{y} 11$ & 1,04103 & 001 \\
\hline & & $\begin{array}{l}25 \text { y1ldan } \\
\text { fazla }\end{array}$ & ,90000 & ,022 \\
\hline \multirow[t]{4}{*}{ Liyakat } & \multirow[t]{3}{*}{$1-4$ y1l } & 5-14 y1l & ,58410 & 015 \\
\hline & & $15-24$ y1l & 1,20370 &, 000 \\
\hline & & $\begin{array}{l}25 \text { yildan } \\
\text { fazla }\end{array}$ & ,99537 & ,003 \\
\hline & 5-14 y11 & $15-24$ y1l & 61961 & ,024 \\
\hline
\end{tabular}


Toplam çalışma süresi değişkenine göre; 1-4 yı1 arası çalışma süresi bulunanların İKY uygulamalarına ilişkin görüşleri ile $15-24$ yıl ve 25 yıldan fazla süredir çalışanların görüşleri arasında anlamlı bir farklılık olduğu ortaya çıkmıştır.

Bunun yanında 1-4 yıl arası çalışma süresi bulunanların liyakat ilkelerine yönelik görüşleri ile 5-14 yı1, 15-24 yıl ve 25 yıldan fazla süredir çalışanların görüşleri arasında anlamlı bir farkl11ık olduğu ortaya çıkmıştır.

Tablo 15. İnsan kaynakları yönetimi uygulamaları ve liyakat ilkelerine ilişkin görüşlerin öğrenim düzeyi değişkenine göre karşılaştırılması

\begin{tabular}{|c|c|c|c|c|c|}
\hline & $\begin{array}{l}\text { Öğrenim } \\
\text { Düzeyi }\end{array}$ & $\mathrm{N}$ & $\begin{array}{c}\text { Sirali } \\
\text { Ortalama }\end{array}$ & Kruskal-Wallis $\mathrm{H}$ & $\mathrm{p}$ \\
\hline \multirow{4}{*}{ Personel } & Lise & 12 & 25,21 & \multirow{4}{*}{4,729} & \multirow{4}{*}{,09 } \\
\hline & Önlisans & 27 & 40,91 & & \\
\hline & Lisans & 34 & 38,06 & & \\
\hline & Toplam & 73 & & & \\
\hline \multirow{4}{*}{ Liyakat } & Lise & 12 & 25,54 & \multirow{4}{*}{4,365} & \multirow{4}{*}{, 11} \\
\hline & Önlisans & 27 & 40,48 & & \\
\hline & Lisans & 34 & 38,28 & & \\
\hline & Toplam & 73 & & & \\
\hline
\end{tabular}

Öğrenim Düzeyi değişkeni ile İKY uygulamaları ve liyakat ilkelerine yönelik görüşlerin Kruskal-Wallis $\mathrm{H}$ testi sonuçlarında 0.05 düzeyinde anlamlı bir farklılık olmadığ 1 ortaya çıkmıştır.

\section{Tartışma, Sonuç ve Öneriler}

Liyakate uygun insan kaynağının yöneltilmesi tüm mecralarca kabul gören bir değer halini almışken aksini gerçekleştiren yöneticilerin ise ağır eleştiriler maruz kaldığı bir dönem içerisinde yer almaktayız. Liyakate esas yöneltmelerin yapılmadığı noktalarda oluşan nepotik durumlarda da yozlaşmanın oryaya çıktığı gibi kurum veya kuruluştaki iç girişimciliklerinde baltalandığı durumu ise yadsınamaz. Sağlık kurumları gibi sıfır hata ile çalışmayı gerektiren hizmet sektöründe, insan kaynağındaki stratejik bakış ve liyakate esas daha önem arz ettiği ortadadır. İnsan hayatının ve sağlığının sürdürülebilirliğini sağlayan sağlık kurumlarındaki iş gücü planlamaları çok dikkatle yürütülmesi gereken yerlerdir. Diğer yandan sağlik sektörü insanların sadece şifa bulup gitmeye gayret ettikleri yerler olmaktan çıkmış artık hastanın tercih boyutları gelişimini de şekillendirdiği yerler halini almıştır.

Stratejik yönetim bir zihin gözüdür de diyebiliriz. Strateji ortaya koyacak kişi veya organizasyonu öncelikle olguları bir araya getirerek kimsenin göremediğini zihni ile görür. Ardından bu gördüklerini hayal ederek birleştirir aralarında bir uyumsama oluşturur. Bir sürece tabi tutarak örgütüne, organizasyonuna, grubuna veya kişisel olarak kendisine uygun bir forma dönüştürerek kabul edilebilirliğini arttırır. Ardından stratejiyi uygulamak için zamanı, mekanı ve kişilerin uygunluğunu sağlayarak gerçekleştirme gayreti içerisine girer. Bunların tamimiyle gerçekleşmesi bir inancın ve felsefik bakışın ürünüdür.

Stratejik insan kaynakları yönlendirmelerindeki oluşacak liyakatli yönlendirmeler örtük bir öğrenme ile ilkesel bir zemin oluşturacak ve iş görenlerce amaç edinme yoluna gidilecektir. Unutulmamalıdır ki nesnel değerlendirmelere tabi tutulmadan yapılan yönlendirmeler stratejik ilerlemeye olumsuz etkiye neden olacaktır.

Bu bilgiler 1şığında yaptığımız çalışma sonucunda aşağıdaki hususlar elde edilmiştir:

İKY uygulamalarına yönelik görüşleri ile liyakat ilkelerine yönelik görüşleri arasında anlamlı bir ilişki olduğu ortaya çıkmıştır. Bu ilişkinin yönüne bakıldığında ise pozitif yönde olduğu tespit edilmiştir. Buna göre katılımcıların IKKY uygulamalarına yönelik görüşleri ile liyakat ilkelerine yönelik görüşler arasında doğrusal yönde bir ilişki olduğu ifade edilebilir. 
Cinsiyet değişkeni ile İKY uygulamaları ve liyakat ilkelerine yönelik görüşlerin MannWhitney U testi sonuçlarında 0.05 düzeyinde anlamlı bir farklılık olmadığı ortaya çıkmıştır. Bu sonuç, katılımcıların kadın veya erkek olmaları açısından İKY uygulamaları ve liyakat ilkelerine yönelik benzer görüşlerde bulunduklarını göstermektedir.

Çalışılan branş değişkeni ile İKY uygulamaları ve liyakat ilkelerine yönelik görüşlerin Kruskal-Wallis H testi sonuçlarında 0.05 düzeyinde anlamlı bir farklılık olduğu ortaya çıkmıştır. Çalışılan branş değişkenine göre; sekreter olarak çalışanların İKY uygulamaları ve liyakat ilkelerine yönelik görüşleri ile büro memuru olarak çalışanların görüşleri arasında anlamlı bir farklılık olduğu ortaya çıkmıştır.

Kurumda çalışma nedeni değişkeni ile İKY uygulamaları ve liyakat ilkelerine yönelik görüşlerin Kruskal-Wallis $\mathrm{H}$ testi sonuçlarında 0.05 düzeyinde anlamlı bir farklılık olduğu ortaya çıkmıştır. Kurumda çalışma nedeni değişkenine göre; iş güvencesinden ötürü kurumda çalışanların İKY uygulamalarına yönelik görüşleri ile yaptığı işin niteliği ve kurumun prestijinden ötürü kurumda çalışanların görüşleri arasında anlamlı bir farklılık olduğu ortaya çıkmıştır. Burada, prestij nedeniyle kurumda çalışanların İKY uygulamaları ve liyakat ilkelerine yönelik görüşlerin benimsenme düzeyinin diğer gruptakilerden daha yüksek olduğu ortaya çıkmıştır.

Kaç defa kurum içi yer değişikliğinde bulunulduğu değişkeni ile İKY uygulamaları ve liyakat ilkelerine yönelik görüşlerin Kruskal-Wallis $\mathrm{H}$ testi sonuçlarında 0.05 düzeyinde anlamlı bir farklılık olduğu ortaya çıkmıştır. Kurum içinde kaç defa yer değişikliğinde bulunulduğu değişkenine göre; hep aynı yerde çalışanların İKY uygulamaları ve liyakat ilkelerine yönelik görüşleri ile 2-5 kez ve 6 ve üzeri kez yer değiştirenlerin görüşleri arasında anlamlı bir farklılık olduğu ortaya çıkmıştır.

Toplam çalışma süresi değişkeni ile İKY uygulamaları ve liyakat ilkelerine yönelik görüşlerin Kruskal-Wallis $\mathrm{H}$ testi sonuçlarında 0.05 düzeyinde anlamlı bir farklılık olduğu ortaya çıkmıştır. Toplam çalışma süresi değişkenine göre; $1-4$ yıl arası çalışma süresi bulunanların IKKY uygulamalarına ilişkin görüşleri ile 15-24 yıl ve 25 yıldan fazla süredir çalışanların görüşleri arasında anlamlı bir farklılık olduğu ortaya çıkmıştır. Bunun yanında 1-4 yıl arası çalışma süresi bulunanların liyakat ilkelerine yönelik görüşleri ile 5-14 yıl, 15-24 yıl ve 25 y1ldan fazla süredir çalışanların görüşleri arasında anlamlı bir farklılık olduğu ortaya çıkmıştır. Elde edilen sonuçlara dönük olarak ortalama değerlerde 1-4 yıl arasında toplam çalışma süresi bulunanların İKY uygulamaları ve liyakat ilkelerine yönelik görüşlerinin daha çok benimsendiği ortaya çıkmıştır.

Öğrenim Düzeyi değişkeni ile İKY uygulamaları ve liyakat ilkelerine yönelik görüşlerin Kruskal-Wallis $\mathrm{H}$ testi sonuçlarında 0.05 düzeyinde anlamlı bir farklılık olmadığ 1 ortaya çıkmıştır. Bu sonuca göre, araştırmamıza katılanların İKY uygulamaları ve liyakat ilkelerine yönelik görüşleri birbirine benzerdir.

Stratejik insan kaynağının öneminin biraz daha arttığı ve anlaşıldığı bugünlerde Covid19 pandemisi dönemi başlıklı yeni değerlendirmeler yapılarak bakış açısı oluşturulabilir. Yine bu çalışma çerçevesinde kamu özel karşılaştırması yapılabilir.

\section{Kaynaklar}

Abujudeh, S. (2019). The Role Of Human Resource Management In Employees'job Satisfaction And Organizational Commitment. Sea-Practical Application of Science, 7(20), 137-145.

Acar, A. (2012). Devlet-Piyasa Sarmalında Memuriyet Statüsünün Konumu: 'Performans'a Karş1 'Liyakat'İle Sorunu Anlayabilmek. Sosyal ve Beşeri Bilimler Dergisi, 4(2), 31-40.

Ahn, H. S., Righter, R. and Shanthikumar, J. G. (2005) Staffing decisions for heterogeneous workers with turnover. Mathematical Methods of Operations Research, 62, 499-514.

Aslan, O. E. (2012). Kamu Personel Hukuku. Eskişehir: TC Anadolu Üniversitesi Yayını, 49. 
Bard, J.F. and Wan, L. (2008) Workforce design with movement restrictions between workstation groups. Manufacturing and Service Operations Management, 10, 24-42.

Bartholomew, D.J., Forbes, A.F. and McClean, S.I. (1991) Statistical Techniques forManpower Planning, second edition, JohnWiley\&Sons, New York, NY.

Bejtkovský, J. (2017). Selected current trends in human resource management in health service providers in the Czech Republic. Acta Universitatis Agriculturae et Silviculturae Mendelianae Brunensis, 65(6), 1833-1840.

Bienstock, D. and Zenteno, A.C. (2012) Models for managing the impact of an epidemic. Access Research Papers, https://core.ac.uk/download/pdf/27294390.pdf (Erişim tarihi: 12.10.2017).

Boudreau, J., Hopp, W., McClain, J. O. and Thomas, L. J. (2003) On the interface between operations and human resourcesmanagement. Manufacturing and Service Operations Management, 5, 179-202.

Brandeau, M.L., Hopkins, D.S.P. and Melmon, K.L. (1987) An integrated budget model for medical school financial planning. Operations Research, 35, 684-703.

Çağatay, A. (2019) Kamu ve Özel Hastanelerdeki Yöneticilerin Stratejik Yönetim Araçları Kullanım Görüşleri Hakkında Karşılaştırmalı Bir Araştırma, Gazi Üniversitesi Sosyal Bilimler Enstitüsü, (ss. 99-100)

de Véricourt, F. and Jennings, O.B. (2011) Nurse staffing in medical units: a queueing perspective. Operations Research, 59(6), 1320-1331.

Dieleman, M., Gerretsen, B., \& van der Wilt, G. J. (2009). Human resource management interventions to improve health workers' performance in low and middle income countries: a realist review. Health Research Policy and Systems, 7(1), 7.

Drucker, P. F. (1995). People and performance: The best of Peter Drucker on management. Routledge.

Dumitrana, M., Radu, G., Glăvan, M. E., \& Jinga, G. (2011). Effective and Efficient Tools in Human Resources Management Control. Petroleum-Gas University of Ploiesti Bulletin, Technical Series, 63(3).

Ernst, A.T., Jiang,H., Krishnamoorthy, M.,Owens, B. and Sier,D. (2004) Anannotated bibliography of personnel scheduling and rostering. Annals of Operations Research, 127, 21144.

Flanagan H. (1997) What change a caring management culture? Health Manpower Management 23, 187-191.

Fleming Fallon, Jr., L. and Mcconnell, CH. R. 2014. Human Resource Management in Health Care: Principles and Practices. 2nd Edition. Burlington: Jones \& Bartlett Learning.

Fry, M. J., Magazine, M. J. and Rao, U. S. (2006) Firefighter staffing including temporary absences and wastage. Operations Research, 54(2), 353-365.

Gallo, P., Mihalcova, B., Vegsoova, O., Dzurov-Vargova, T., \& Busova, N. (2019). Innovative Trends in Human Resources Management: Evidence for the Health Care System. Marketing and Management of Innovations, Issue 2, 2019, 11-20. 
Gans, N. and Zhou, Y.P. (2002) Managing learning and turnover in employee staffing. Operations Research, 50(6), 991-1006.

Gass, S.I., Collins, R.W., Meinhardt, C.W., Lemon, D.M. and Gillette, M.D. (1988) The army manpower long-range planning system. Operations Research, 36, 5-17.

Grinold, R.C. (1976) Manpower planning with uncertain requirements. Operations Research, 24, 387-399.

Guest, D. E. (1987). Human resource management and industrial relations [1]. Journal of management Studies, 24(5), 503-521.

Gupta, N., Diallo, K., Zurn, P. and Poz, M. R. D. (2003). “Assessing Human Resources For Health: What Can Be Learned From Labour Force Surveys?”, Human Resources for Health, $1-16$.

Healthcare Management (2011), The healthcare Workforce 17. Chapter Paula Hyde and Anne McBride, Open University Press Editors: Walse K. \& Simth. J. (ss.347-400).

Hermanowicz, J. C. (2019). The Degradation of Merit. Society, 56(4), 340-347.

Hitka, M., Lorincová, S., Bartáková, G. P., Ližbetinová, L., Štarchoň, P., Li, C., \& Mura, L. (2018). Strategic tool of human resource management for operation of SMEs in the woodprocessing industry. BioResources, 13(2), 2759-2774.

Kabene, S. M., Orchard, C., Howard, J. M., Soriano, M. A., \& Leduc, R. (2006). The importance of human resources management in health care: a global context. Human resources for health, 4(1), 20.

Kıdak, 1. B., Arslan, E. T., \& Demir, H. (2016). Acil Sağlık Hizmetlerinde İnsan Kaynakları Yönetimi Problemlerinin Belirlenmesi Ve Analitik Hiyerarşi Prosesi İle Önceliklendirilmesi: Ambulans Servisi Örneği. Süleyman Demirel Üniversitesi Vizyoner Dergisi, 7(16), 1-15.

Kuhlmann, E. and Larsen, C. (2015). "Why We Need Multi-Level Health Workforce Governance: Casestudies From Nursing And Medicine In Germany”, Health Policy, 119(12), 1636-1644.

Lammintakanen, J., Saranto, K., Kivinen, T., \& Kinnunen, J. (2002). The digital portfolio: a tool for human resource management in health care?. Journal of nursing management, 10(6), 321328.

Martel, A. and Price,W. (1981) Stochastic programming applied to human resource planning. Journal of the Operational Research Society, 32, 187-196.

Mathauer, I., \& Imhoff, I. (2006). Health worker motivation in Africa: the role of non-financial incentives and human resource management tools. Human resources for health, 4(1), 24.

Niles, N. J. (2013). Basic Concepts of Health Care Human Resource Management. 1st ed. Burlington: Jones \& Bartlett Learning.

Onnis, L. A. (2019). Human resource management policy choices, management practices and health workforce sustainability: remote Australian perspectives. Asia Pacific Journal of Human Resources, 57(1), 3-23.

Öztürk, A. T., (2008) Değişen Çağın Aile İşletmelerinde Kurum Kültürünün Yerleştirilmesinde Profesyonel Yöneticilerden Beklentiler, 3. Aile İşletmeleri Kongresi Kongre Kitabı, (ss. 464). 
Peretomode, V. F., \& Peretomode, O. (2001). Human resources management. Lagos: Obaroh and Ogbonaka Publishers.

Perotomode, V. E and Perotomode, O., (2001). Human Resources Management, Lagos: Obaroh and gbinaka Publishing Company.

Pinker, E.J. and Shumsky, R.A. (2000) The efficiency-quality trade-off of cross-trained workers. Manufacturing and Service Operations Management, 2, 32-48.

Ramazan, G. (2019) Türk Eğitim Sisteminde Liyakat (Meritokrasi) Esaslı Eğitim Yöneticiliği. Mehmet Akif Ersoy Üniversitesi Ĕ̈itim Fakültesi Dergisi, (52), 39-64.

Rao, P.P. (1990) A dynamic programming approach to determine optimal manpower recruitment policies. Journal of the Operational Research Society, 41, 983-988.

Sezer, Y. (2003). Kamu Hizmetine Girme Hakkı Ve Liyakat İlkesi Açısından İstisnai Memurluklar. Selçuk Üniversitesi Hukuk Fakültesi Dergisi, 11(3-4 (Cumhuriyetimize 80. YIL Armağan1)), 173-193.

Shepheard, J. (2011). Industrial relations and human resources: management challenges for Health Information Managers. (ss. 4-6)

Sohag, A., Wajidi, F. A., Miankhel, A. K. (2013). Impact of decentralization on the effectiveness of human resource management in health sector. Gomal University Journal of Research, 29(1), 56-61.

Song, H. and Huang, H.C. (2008) A successive convex approximation method for multistage workforce capacity planning problem with turnover. European Journal of Operational Research, 188(1), 29-48.

Şahin, B. (2016). Kamu Personel Sisteminde İşe Girme Ve Yükselmede Çağdaş Liyakat Kavramları. Çukurova Üniversitesi Sosyal Bilimler Enstitüsü Dergisi, 25(1), 231-242.

Tandu, E. O., Okoro, A. S., Ogun, S. O., \& Etta, P. T. (2016). Human resource management tool of motivation and employees job satisfaction in an organization. Global Journal of Social Sciences, 15(1), 47-54.

Tunçer, M. (2017). Stratejik Insan Kaynakları Yönetimi Ve Liyakat İlkesi: Ege Üniversitesi Tıp Fakültesi Örneği, (Yüksek lisans tezi), İzmir Kâtip Çelebi Üniversitesi, Sosyal Bilimler Enstitüsü, İzmir.

Turner, J.,Mehrotra, S. and Daskin, M. S. (2010) Perspectives on health-care resource management problems, in A Long View of Research and Practice in Operations Research and Management Science, Springer, New York, NY, pp. 231-247.

Türk Dil Kurumu Sözlüğü www. https://sozluk.gov.tr/“liyakat” (Erişim tarihi: 25.04.2020).

Vairaktarakis, G. and Winch, J.K. (1999) Worker cross-training in paced assembly lines. Manufacturing and Service Operations Management, 1, 112-131.

Waterman , R.H., What America Does Right, W.W.Norton, 1994. (ss. 2)

Yankovic, N. and Green, L.V. (2011) Identifying good nursing levels: a queuing approach. Operations Research, 59(4), 942-955. 
Yıldız, G. (2016). Türk kamu yönetiminde liyakat ilkesi. Gazi Üniversitesi Sosyal Bilimler Dergisi, 3(8), 140-180.

\section{ETIKK ve BİLIMSEL İLKELER SORUMLULUK BEYANI}

$\mathrm{Bu}$ çalışmanın tüm hazırlanma süreçlerinde etik kurallara ve bilimsel atıf gösterme ilkelerine riayet edildiğini yazarlar beyan eder. Aksi bir durumun tespiti halinde Afyon Kocatepe Üniversitesi Sosyal Bilimler Dergisi'nin hiçbir sorumluluğu olmayıp, tüm sorumluluk makale yazarlarına aittir. Yazarlar etik kurul izni gerektiren çalışmalarda, izinle ilgili bilgileri (kurul adı, tarih ve sayı no) yöntem bölümünde ve ayrıca burada belirtmişlerdir. Etik Kurulu

Kurul adı: Tokat Gaziosmanpaşa Üniversitesi Sosyal ve Beşeri Bilimler Araştırmaları

Tarih: 25/06/2020

No: E.29031

\section{ARAŞTIRMACILARIN MAKALEYE KATKI ORANI BEYANI}

1. yazar katk1 oranı: $\% 50$

2. yazar katk1 oranı: $\% 50$ 